\title{
1213 中性子ラジオグラフィ熱流動可視化・計測技術
}

\section{Neutron Radiography Flow Visualization and Measurement Technique}

\author{
正 ○呉田 昌俊（原研），正 秋本 肇（原研）
}

\begin{abstract}
Masatoshi KURETA, Japan Atomic Energy Research Institute, Tokai, Ibaraki Hajime AKIMOTO, Japan Atomic Energy Research Institute, Tokai, Ibaraki
\end{abstract}

\begin{abstract}
In this manuscript, neutron radiography $(\mathrm{NR})$ flow measurement techniques, which can measure the void fraction of boiling flow in narrow metal channels, were described. These techniques, high-frame-rate NR (HFR-NR) and NR3DCT, have been developed to study the void fraction and critical heat flux models. Measurement systems are consist of watercirculating loop with a NR test section, pre-heater, separator, condenser and DC power supply to generate the vapor, neutron-visible light converter, camera system which is automatically controlled by the computer and CT system in case of NR3DCT. NR images are processed on the parallel super computer system. Exclusive image processing and visualization software calculates the void fraction and crops the data. Instantaneous void fraction can be measured by HFR-NR with time-resolution of $1 \mathrm{~ms}$. Spatial void fraction distribution can be measure by NR3DCT with spatial-resolution of $100 \mu \mathrm{m}$. These two NR techniques make up the loss mutually, and we can obtain the spatial void fraction with high time resolution.
\end{abstract}

Key Words : Flow Measurement, Neutron Radiography, Void Fraction, Multi-phase Flow, Forced Convection

\section{1. はじめに}

日本原子力研究所 (原研) が設計開発を進めている加速器夕 一グットや革新的軽水炬の炬心 ${ }^{1)}$ の熱設計では、限界出力の評 価が極めて重要である。しかしながら、従来の限界熱流束 (CHF) 相関式やモデルの計算精度は低下し、特にCHF モデル ではボイド率計算に問題があった。ボイド率データが解析の検証 に必要であるが、流れを乱す探針法等は適用できず、また X （y）線法は金属流路内の僅かな水の識別が困難であった。一方、 中性子線は鉄などの金属を透過しやすく水に対して感度が高い特 徵を有し、金属流路内のボイド率を 2 次元で同時計測できる。中 性子線を用いた計測では、散乱中性子線に対する考虑が必要であ り、多くの流動パラメータ毎に記録した大量のデータを正確かつ 高速に処理するシステムの開発が不可欠であった。

本報では、著者が独自に開発した中性子ラジオグラフィ(NR) によるボイド率計測法に関して記し、ボイド率データの流体工学 的考察は別の機会に譲る。本報では、中性子ラジオグラフィ高速 度撮像法 (High-Frame-Rate NR; HFR-NR) と中性子ラジオグラフ 13 次元 CT 法 (NR3DCT) の 2 種類のボイド率計測技術を記す。

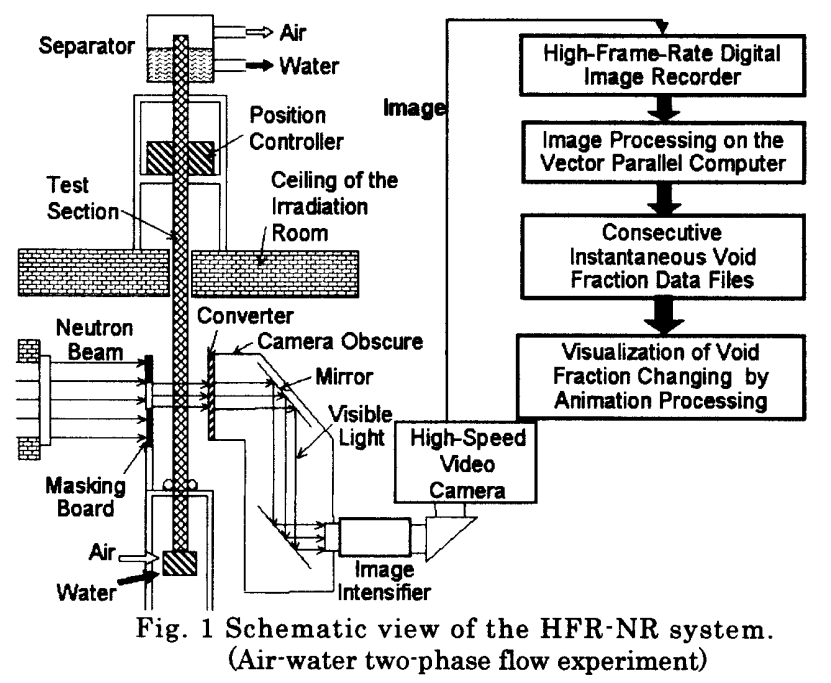

\section{NRボイド率計測システム}

本システムは、中性子源（原研の研究炉 JRR-3M の中性子照 射室) に設置した実験装置と定量化処理・可視化を行う計算機で 構成される。

2.1 HFR-NR HFR-NR は、NR 画像を高速度ビデオを用いて約 $1 \mathrm{~ms}$ の時間分解能で 2 次元の瞬時ボイド率を連続的に計測でき $3^{2)}$ 。空間分解能は約 300 1000 $\mu \mathrm{m}$ であり、計測誤差は $18 \%$ 以下である。図 1 に HFR-NR の概略を示す。試験体を透過した 中性子線は蛍光コンバータで可視光に変換され、その強度から透 過量を計測する。HFR-NR では、高速度ビデオカメラとレンズの 間に 2 段のイメージ・インテンシファイア (II) を挟み光の強度 を増幅させる。記録速度は、500２250 ルーム秒に設定した。NR 画像は $256 \times 256$ ピクセルで 256 階調のグレースケールのデジタ 儿画像として連続的に記録した。これを並列計算機に転送し、計 算機内で輝度補正・位置補正・定量化処理等を行うことにより、 連続した瞬時ボイド率分布を得た。連続 2 次元データは、アニメ ーション表示により気泡や液膜の挙動を詳細に観察した。なお、 図 1 は空気一水二相流のボイド率計測の設定を示している。

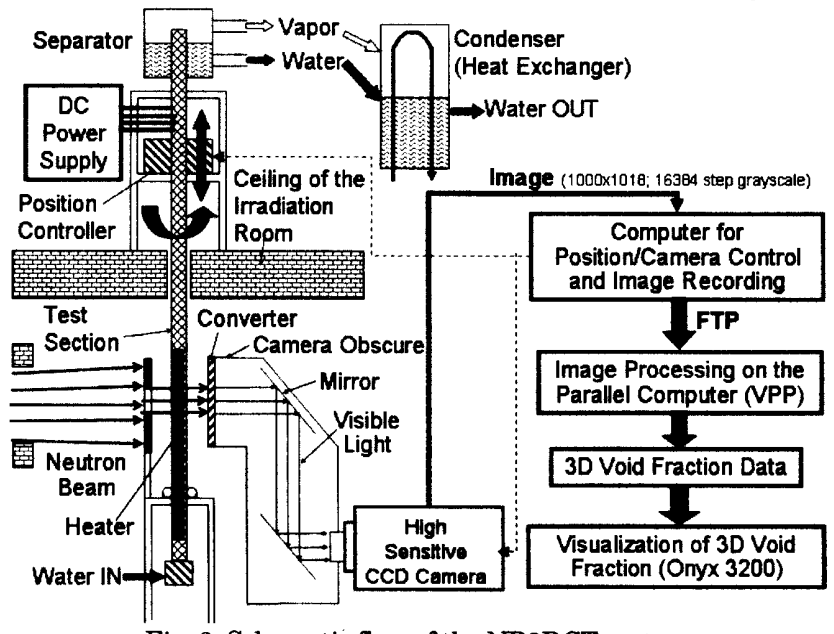

Fig. 2 Schematic flow of the NR3DCT system. (Boiling two-phase flow experiment) 


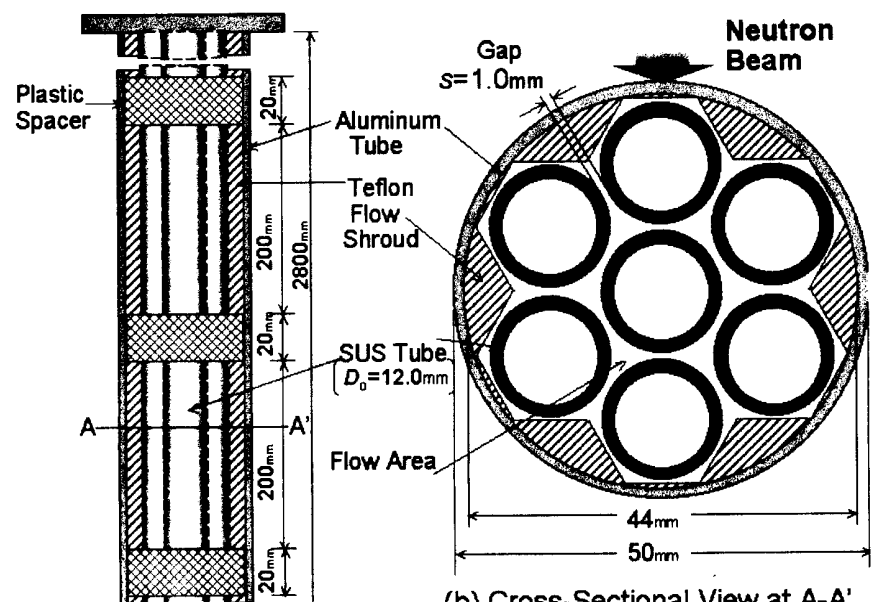

(b) Cross-Sectional View at A-A' (a) Side View

Fig. 3 Dependence of liquid-layer thickness on superficial momentum flux.

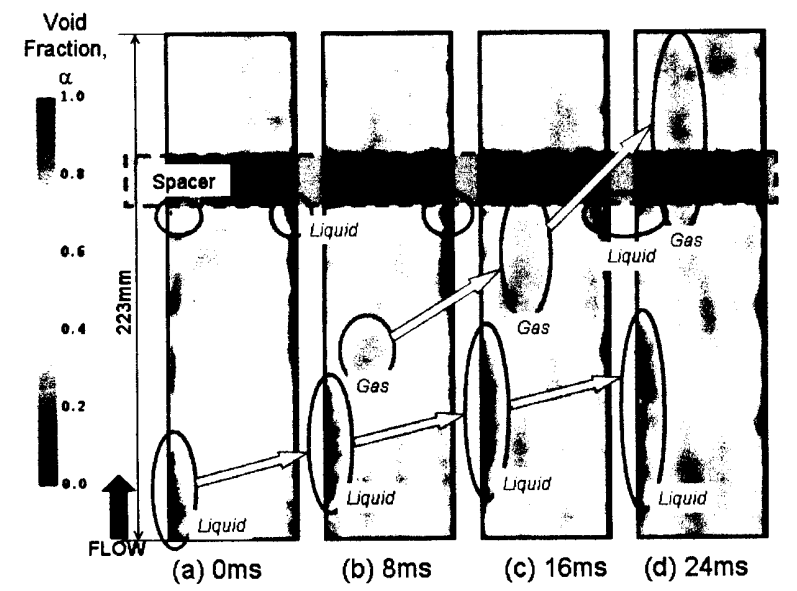

Fig. 4 Consecutive images of the instantaneous void fraction at the annular flow condition measured by HFR-NR.

2.2 NR3DCT NR3DCT は、図 2 に示すように試醛体を上下・回転 させ、投影 NR 画像の CT 再構成によりボイド率の 3 次元分布を 計測する技術である。NR 画像は冷却型 CCD カメラ（バックグ ラウンドノイズを低减するため $\mathrm{CCD}$ 素子をー30 ジタルカメラで高感度撮影が可能）を用いて約 $100 \mu \mathrm{m}$ ボクセル の空間分解能でボイド率を計測した。カメラと CT 装置を連動さ せ画像を自動で記録した。試験体の位置 $(\theta, z)$ が異なる画像 をデジタル画像の形で計算機に転送した。計算機上では、 $\gamma$ 線， イズの除去、位置補正、輝度補正、定量化 CT 再構成、可視化の ための処理等をMPIを用いて複数の CPU に分散処理し 3 次元の ボイド率分布を得た。CT 再構成は、SheppLLogan フィルタ ${ }^{3)}$ 補正したコンボルーション逆投影法を採用した。

データ処理ソフトは、基幹ソフトが並列処理に対応した CUI ソフトであり、データの可視化は HFR-NR では 2Dデータを Motif $+C$ 言語で開発した GUI ソフトで、NR3DCT では2D+3D データ をAVS+C 言語を用いて開発したGUI ソフトで行った。

\section{3. 实験結果}

試験体の 1 例を図 3 に示す。本試験体は将来型原子炉の炉心を 模擬しており、稠密バンドル流路内の空気一水二相流や沸騰流の ボイド率を HFR-NR 及び NR3DCT を用いて計測することを目的 として製作した。図 4 に、HFR-NRを用いて空気一水二相流の瞬 時ボイド率分布の時間変化を計測した例を示す。ボイド率の定量 化により試験体の構成部材は画像から消えボイド率の変化のみが 観察できる。本 HFR-NRの結果から、ボイド率が 0.8 以下では周 辺部やスペーサ下部に水が滞りやすいことが分かり、ドリフト・

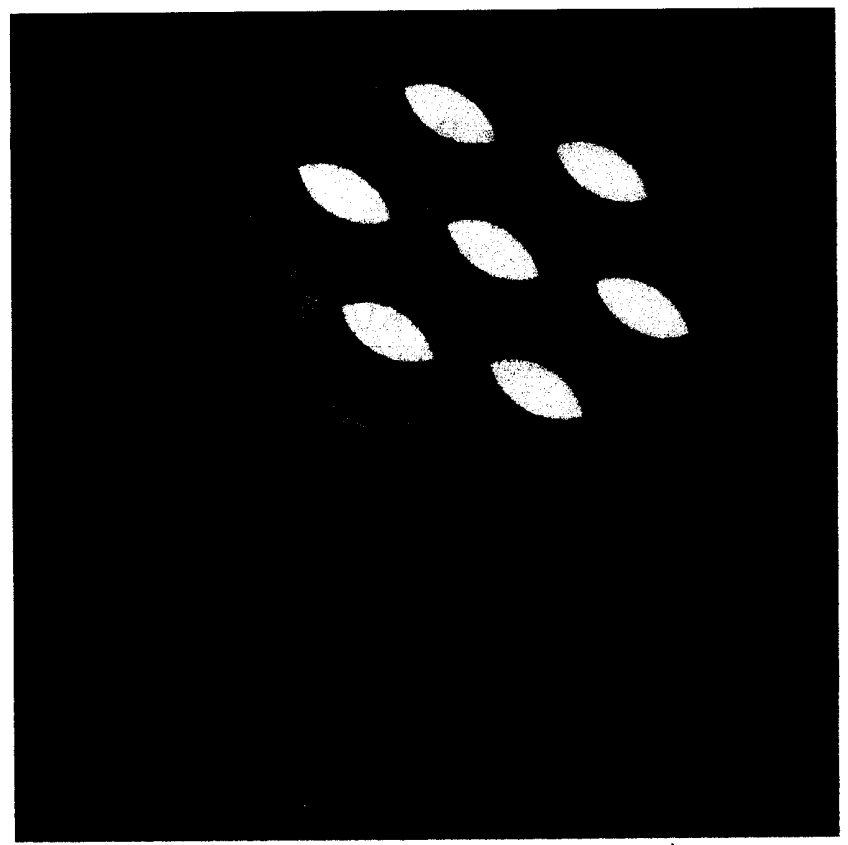

(a) Test section data (Stainless steel tubes)

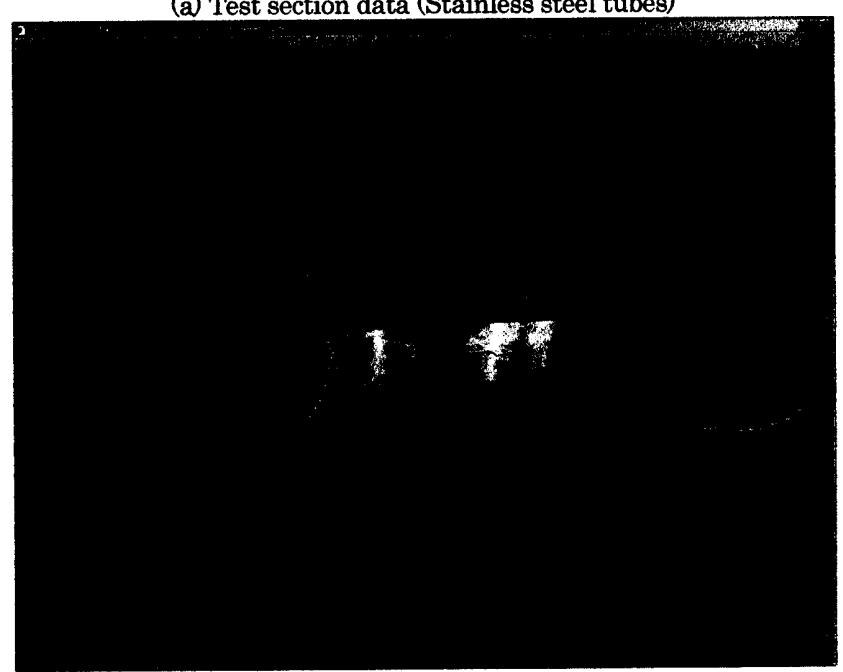

(b) Air-water two-phase flow data

Fig. 5 3D void fraction distribution measured by NR3DCT.

フラックスモデルによるボイド率相関式が開発できた。図 5 に NR3DCT で計測した空気一水二相流のボイド率分布の 1 例を示 す。図 5(a)は、ステンレス製円管の可視化例を、図 5(b)は、二相 流のボイド率分布を示している。現在、計測結果を専用ソフトや VRML で表示したり、立体視（VR）したりすることで現象の理 解を行っている。また、計測したボイド率の 3 次元データは詳細 熱流動解析コードやサブチャンネル解析コードの検証用データに 役立てられる。

\section{4. 今後の課題}

HFR-NRの基本技術は確立したが、NR3DCT は高精度化・高速 化の余地がある。高精度化では、散乱中性子線や CT 再構成アル ゴリズムに起因する精度低下の改善が課題である。

\section{5. まとめ}

中性子ラジオググラフィ高速度撮像法および中性子ラジオグラ フィ 3 次元 CT 法の研究開発を行い、これらの計測技術がボイド 率計測の新手法として有効であることを示した。

\section{参考文献}

(1) 大久保他 2名, JAERHResearch, 2001-21(2001).

(2) 呉田他 3 名, 機論(B), 67-653, 179-188(2001).

(3) Shepp 他 1 名, IEEE Trans. on Nuclear Science, 21(6), 2143(1974). 